\title{
Adhesion and spreading of cultured endothelial cells on modified and unmodified poly (ethylene terephthalate): a morphological study
}

\author{
P.B. van Wachem*, J.M. Schakenraad**, J. Feijen*, T. Beugeling*, \\ W.G. van Aken*, E.H. Blaauw ${ }^{\dagger}$, P. Nieuwenhuis** and I. Molenaar ${ }^{\dagger}$ \\ ${ }^{*}$ Department of Chemical Engineering. Twente University, PO Box 217, 7500 AE. Enschede, The Netherlands; ${ }^{* *}$ Department \\ of Histology and ${ }^{\dagger}$ Centre for Medical Electron Microscopy, Oostersingel 69/1 and 69/2, 9713 EZ, University of Groningen. \\ Groningen, The Netherlands \\ (Received 14 March 1988; revised 18 July 1988; accepted 20 September 1988)
}

\begin{abstract}
The in vitro adhesion and spreading of human endothelial cells (HEC) on hydrophobic poly(ethylene terephthalate) (PETP) and moderately wettable tissue culture poly(ethylene terephthalate) (TCPETP) were studied with light microscopy and electron microscopy. Numbers of HEC adhering on TCPETP were always higher than those found on PETP. When cells were seeded in the presence of serum, extensive cell spreading on both PETP and TCPETP was observed after the first $\mathbf{3 0}$ min. Thereafter, spread cells appeared to withdraw from the PETP surface, resulting in irregularly shaped cells. Complete cell spreading occurred on TCPETP. Complete cell spreading also occurred on PETP and TCPETP when HEC had first been seeded from phosphate buffer solution and serum was supplied after $\mathbf{3 0}$ min. Furthermore, HEC spread on both PETP and TCPETP when the surfaces were precoated with protein(s), which promotes cell adhesion. However, when plasma was used for the coating, spread cells did not proliferate in a monolayer pattern. This study shows that TCPETP is, in general, a better surface for adhesion and proliferation of HEC than is PETP, suggesting that vascular prostheses with a TCPETP-like surface will perform better in vivo than prostheses made of PETP.
\end{abstract}

Keywords: Cell adhesion, endothelium, poly(ethylene terephthalate)

After implantation of vascular prostheses, an inner lining consisting of cells and other compounds, often called pseudo- or neo-intima forms. When prostheses are implanted in animals, the inner lining will in time be covered with endothelial cells. This is in contrast with the neo-intima of prostheses implanted in humans which do not contain endothelial cells, except when the prostheses have been preseeded with these cells ${ }^{1}$. Seeding of prostheses with endothelial cells, preferably at implantation, often improves their efficacy, because the formation of a confluent endothelial cell layer is stimulated ${ }^{2,3}$.

In vitro studics on the effects of surface properties of artificial materials on the interaction with seeded human endothelial cells (HEC), in both the presence and absence of

Correspondence to Dr P.B. van Wachem. serum proteins, may lead to the development of small diameter vascular grafts with a functional endothelial lining.

We previously investigated the influence of polymer surface wettability on the adhesion of HEC in the presence of serum-containing culture medium. HEC adhere, spread and proliferate on tissue culture poly(ethylene terephthalate) (TCPETP), presumably a glow discharge-treated poly(ethylene terephthalate) which is more water-wettable than untreated poly (ethylene terephthalate) (PETP). Reduced HEC adhesion and incomplete spreading were observed on PETP ${ }^{4}$. Furthermore, we demonstrated that HEC adhesion, spreading and proliferation did occur on PETP after precoating this surface with plasma, fibronectin (Fn) or fibrinoge ${ }^{5}$.

In this study the morphology of adhering and proliferating HEC on TCPETP and PETP was evaluated. The effect of the presence of serum in the culture medium as well 
as the influence of pretreatment of the substrates with whole blood, plasma or a fibronectin solution on the cell-polymer interactions were examined.

\section{MATERIALS AND METHODS}

\section{Materials}

Tissue culture poly(ethylene terephthalate) (TCPETP) was obtained from Becton Dickinson, Oxnard, CA, USA (Falcon film-lined dish). TCPETP has a contact angle of $44^{\circ}$, as measured with the captive bubble method ${ }^{4}$. Poly(ethylene terephthalate) (PETP) was obtained from ICl, Rotterdam, The Netherlands (Melinex polyester film, type 0 , contact angle $=$ $\left.65^{\circ}\right)^{4}$.

Specimens of PETP were cleaned ultrasonically in a $1 \%(v / v)$ detergent solution (RBS 25, Hicol, Rotterdam, The Netherlands) for $30 \mathrm{~min}$, followed by extensive rinsing with distilled water and ethanol ${ }^{4}$. The specimens were then dried at ambient conditions. The surface wettability of the material was not altered by this treatment.

Specimens of TCPETP, used as received from the manufacturer, and specimens of cleaned PETP were mounted into modified 'Bionique' growth chambers (Corning, New York, USA), as described previously ${ }^{4}$.

\section{Methods}

Cell culture. Endothelial cells were isolated from human umbilical cord veins according to the isolation method described by Jaffe et al. ${ }^{6}$ with some modifications ${ }^{7}$.

Cells were routinely cultured in tissue culture polystyrene (TCPS) flasks (Corning, New York, USA) precoated with a fibronectin solution for $1 \mathrm{~h}\left(\mathrm{Fn}^{\mathrm{c}}\right.$, a $2 \%$ solution $(\mathrm{w} / \mathrm{v})$ of crude fibronectin in complete medium (see later)). Crude fibronectin was obtained from the Central Laboratory of the Netherlands Red Cross Blood Transfusion Service, Amsterdam, The Netherlands. This fibronectin is a coproduct obtained during the preparation of coagulation factor VIII from cryoprecipitate. The serum-containing culture medium (CMS) consisted of complete medium, an equal mixture of Medium M 199 and Medium RPMI 1640 (both from Gibco Biocult Co., Paisley, UK), with $2 \mathrm{mM}$ L-glutamine (Merck, Darmstadt, Federal Republic of Germany), 100 units $/ \mathrm{ml}$ penicillin, $100 \mu \mathrm{g} / \mathrm{ml}$ streptomycin (both from Flow Lab., Irvine, UK) and $2.5 \mu \mathrm{g} / \mathrm{ml}$ fungizone (Gibco), which was supplemented with $20 \%$ human serum (pool from 20 healthy male donors). Cells were used for experiments after the third passage when the culture had reached confluence. Harvesting of cells for subculturing or testing was performed with a trypsin solution (0.05\% trypsin/0.02\% EDTA, Gibco). Trypsin was subsequently inactivated with CMS.

\section{Experiments}

Three series of experiments $(a, b, c)$ were carried out to study the morphology of HEC interacting with PETP and TCPETP. For each series, HEC were used which had been cultured from a different umbilical cord vein.

In series a, short-term HEC adhesion on to TCPETP was studied. A seeding density of $4 \times 10^{4}$ cells $/ \mathrm{cm}^{2}$ was applied. Incubation was carried out at $37^{\circ} \mathrm{C}$. HEC were either immediately seeded from CMS and incubated for 5, 10, 20 or $30 \mathrm{~min}$, or (to examine HEC interactions under serum-free conditions) first washed three times with phosphatebuffered saline (PBS) and then seeded from PBS. After
$30 \mathrm{~min}$. PBS was replaced by CMS and adhesion in CMS was monitored up to 30 min after the addition of CMS.

In series $b$, adhesion on to PETP was examined. The experiment was carried out, as described for series a, but with additional incubation times of 1 and $2 \mathrm{~h}$, both when HEC had been seeded from CMS and when HEC had been preincubated in PBS for 30 min.

In series $\mathrm{C}$, adhesion and proliferation of HEC in CMS on (protein-precoated) TCPETP and PETP were investigated. TCPETP and PETP were pretreated with whole blood, plasma or a $\mathrm{Fn}^{\mathrm{c}}$ solution for $1 \mathrm{~h}$ at r.t.. Whole blood from a healthy donor was obtained by vena puncture without using anticoagulants and immediately used for pretreatment of surfaces. Plasma, pooled from six healthy male donors, was obtained from the Red Cross Bloodbank, Twente, Enschede, The Netherlands.

The ratio of the volume of the protein solution $(\mathrm{ml})$ used for precoating to the area $\left(\mathrm{cm}^{2}\right)$ of the polymer surface in the growth chamber was 0.2 . After precoating, the test surfaces were extensively rinsed with PBS. The adhesion and spreading of $\mathrm{HEC}$ were examined $30 \mathrm{~min}$ and $2 \mathrm{~h}$ after seeding.

\section{Scanning and transmission electron microscopy (SEM, TEM)}

After the appropriate incubation time, the substrates were washed once with PBS and the adherent HEC were fixed with $0.5 \%$ glutaraldehyde and $0.5 \%$ formaldehyde $(\mathrm{v} / \mathrm{v})$ in PBS. For SEM, the specimens were flushed for $30 \mathrm{~min}$ with $6.8 \%$ sucrose $\mathrm{v} / \mathrm{v}$ in $0.1 \mathrm{M}$ PBS, $\mathrm{pH}=7.4$. Post-fixation was carried out for $3 \mathrm{~h}$ with $1 \% \mathrm{OsO}_{4}\left(\mathrm{~V} / \mathrm{V}\right.$ in PBS) at $4{ }^{\circ} \mathrm{C}$ followed by dehydration with ethanol and substitution with n-amyl acetate. After critical-point drying with $\mathrm{CO}_{2}$, the specimens were sputter-coated with gold/palladium. The specimens were examined in a DS130 scanning electron ISI-microscope. SEM was used to examine cell morphology and to determine cell spreading by measuring the surface area of adhering cells. This was carried out by projecting enlarged SEM photonegatives with adherent cells on a digitizer tablet (Apple $\left.A_{2} M_{2} 007\right)^{8}$. Data $\left(\mu \mathrm{m}^{2}\right.$ ) are expressed as the mean surface area of 45 randomly chosen cells ( \pm standard error of the mean, s.d.) for each substrate after the time interval concerned. Tissue culture polystyrene (TCPS), precoated with $\mathrm{Fn}^{\mathrm{c}}$, was used as the control substrate.

For TEM, specimens were flushed with PBS and postfixed with $1 \% \mathrm{OsO}_{4}$ in PBS $(1 \mathrm{~h})$. After dehydration with ethanol, samples were embedded in Epon 812. Ultrathin sections perpendicular to the monolayer of HEC in contact with the (pretreated) polymeric surfaces were stained for $45 \mathrm{~min}$ with $5 \%$ uranyl acetate, followed by 2 min with lead citrate $(120 \mathrm{mM})$. TEM micrographs were made with a Philips 201 transmission electron microscope operated at $40 \mathrm{kV}$. TEM was used to examine cell morphology, especially in the contact area between the cell and the substrate. Mean distances between cell and substrate were determined at the central part of the cell (about $6 \mu \mathrm{m}$ in length).

\section{RESULTS}

\section{Cell spreading}

In the presence of serum-containing culture medium (CMS), HEC showed a gradual increase of spreading immediately after seeding on both TCPETP and PETP (Figure 1). The 


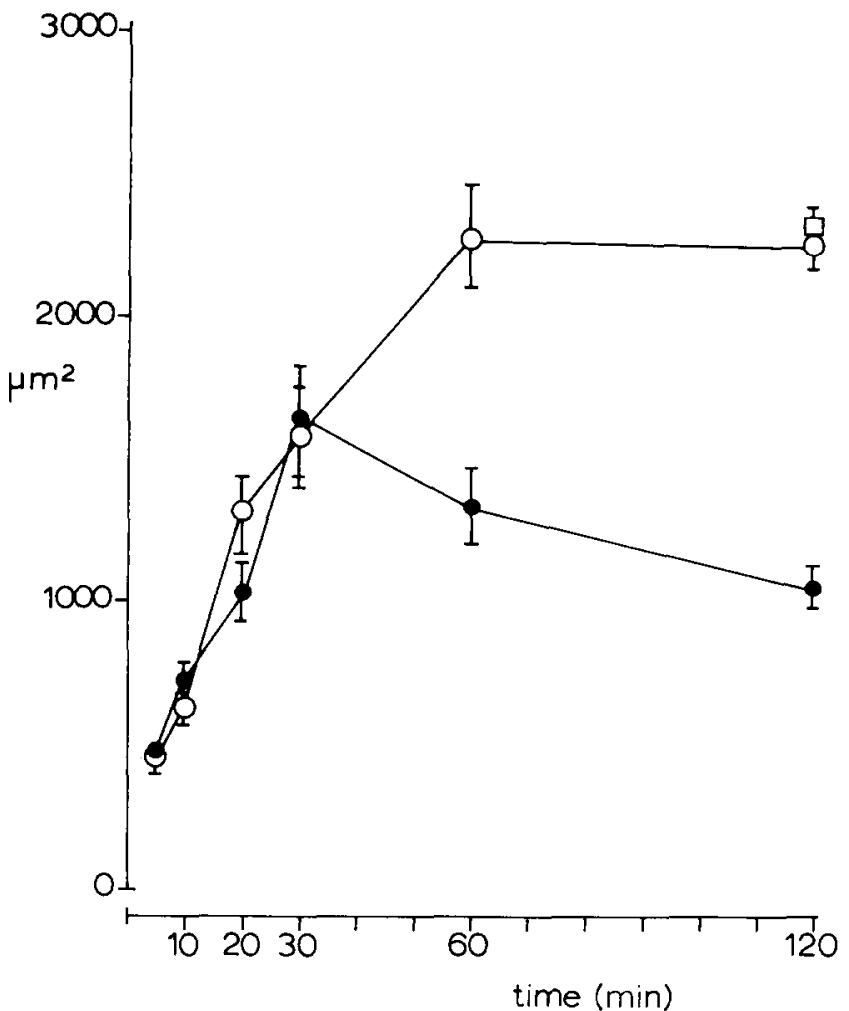

Figure 1 Adhesion of HEC on to TCPETP (O) and PETP (๑). $4 \times 10^{4}$ cells $/ \mathrm{cm}^{2}$ were seeded from CMS. Cell spreading was measured by use of a digitizer tablet. Data $\left(\mu \mathrm{m}^{2}\right)$ are expressed as the mean surface area of 45 cells $( \pm S D)$ on the substrate at a specific time interval. The control substrate was TCPS, pretreated with $\mathrm{Fn}^{\mathrm{c}}$ ( $\square$ ).

adhering $\mathrm{HEC}$ reached a mean surface area of approximately $1600 \mu \mathrm{m}^{2}$ at $30 \mathrm{~min}$ on both substrates. Upon further incubation, cell spreading on TCPETP continued until a plateau value of $2200 \mu \mathrm{m}^{2}$ was reached. The same value was measured for HEC, which had been incubated with the control substrate, $\mathrm{Fn}^{\mathrm{c}}$-pretreated TCPS. In contrast, cell spreading on PETP decreased after $30 \mathrm{~min}$, reaching a value of about $1100 \mu \mathrm{m}^{2}$ after an additional incubation of $90 \mathrm{~min}$ in CMS.

Under serum-free conditions, spreading values of approximately $700 \mu \mathrm{m}^{2}$ were found on all three substrates at 30 min (Figure 2). When PBS was replaced by CMS at $30 \mathrm{~min}$, the cell spreading on both TCPETP and PETP increased to approximately $2000 \mu \mathrm{m}^{2}$ at $60 \mathrm{~min}$. No decrease in cell spreading was observed on PETP after an additional 90 min incubation in CMS.

\section{Scanning and transmission electron microscopy}

HEC adhesion on to TCPETP (series a). Short-term adhesion of HEC on to TCPETP was examined by SEM and TEM after cell seeding in the presence of CMS (Figure 3). Both the number of adhering HEC, and the spreading area of individual cells, increased as a function of time (Figures $3 a, b)$. Not all HEC had completely spread within $30 \mathrm{~min}$ (Figure 3b). Cells had a circular morphology (broad circular lamellae). Overlap of cell margins was observed by TEM. The cell margins adhered to the substrate (close contacts) and to neighbouring cells (Figure $3 c$ ). The average distance between the membrane at the central part of the cells and the substrate was approximately $50 \mathrm{~nm}$ (Figure $3 d$ ). A dense and very thin layer of adsorbed proteins was present between the substrate and the adherent cells. Several membrane vesicles, both at the side of the substrate and at

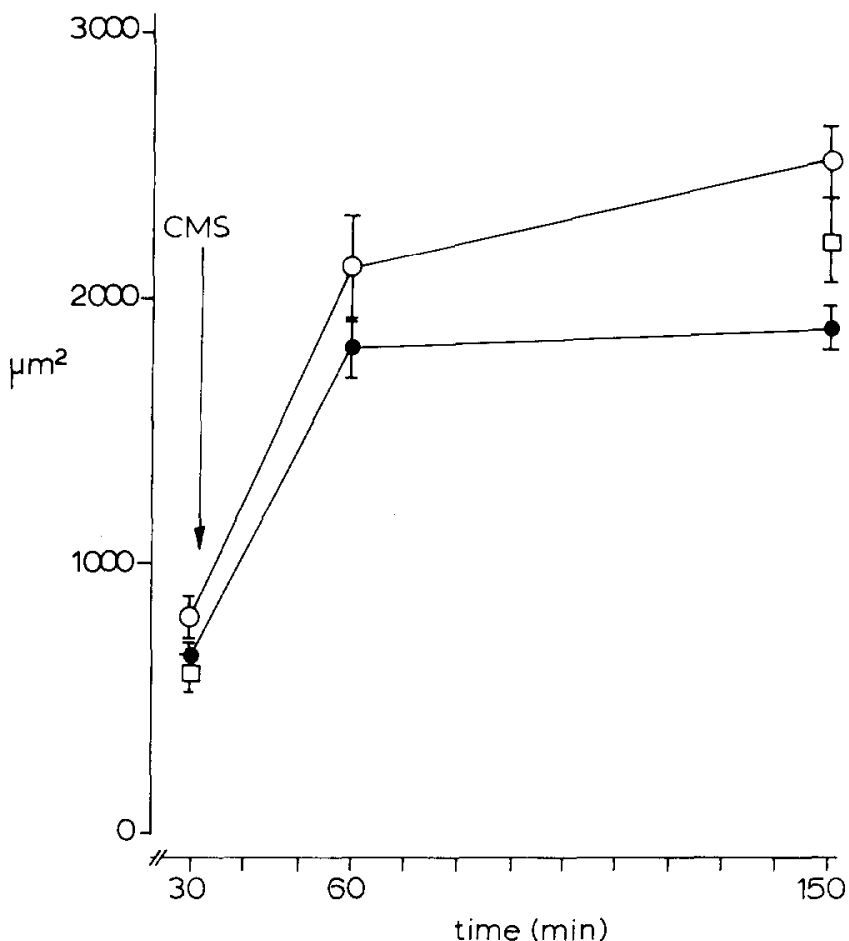

Figure 2 Adhesion of HEC on to TCPETP (O) and PETP (-). $4 \times 10^{4}$ $\mathrm{cel} / \mathrm{s} / \mathrm{cm}^{2}$ were seeded from PBS. At $30 \mathrm{~min}$, PBS was removed and replaced by $C M S$. Cell spreading was measured by use of a digitizer tablet. Data $\left(\mu \mathrm{m}^{2}\right)$ are expressed as the mean surface area of $45 \mathrm{ce} / / \mathrm{s}( \pm S D)$ on the substrate at a specific time interval. The control substrate was TCPS, pretreated with $\mathrm{Fn}^{\mathrm{C}}$ ( $\square$ ).

the luminal side, were observed (Figure 3d). When HEC had been seeded from PBS, fewer cells adhered to TCPETP after $30 \mathrm{~min}$ (compare Figures $4 a$ and $3 b$ ). The adhering and spreading cells showed different morphologies, as observed by SEM (Figure 4a). Some cells showed the circular and spread morphology described above, but most cells showed hardly any cell spreading at all. Other cells seemed to be in a stage between these two forms, thereby extending various types of cytoplasmic processes (compare with HEC seeded from CMS, Figure $3 b$ ). Five minutes after the addition of CMS, cells adhering to the cytoplasmic process of another cell were observed (Figure $4 b$ ). After $30 \mathrm{~min}$ in the presence of serum, the cytoplasmic processes had broadened and many cells showed complete flattening in close contact $( \pm 30 \mathrm{~nm})$ with the substrate. However, the remaining features of the cytoplasmic processes (i.e. membrane ruffling), which were first seen to protrude from cells in the presence of PBS, could still be observed (Figure 4c). TEM showed spread cells and complex interdigitations (Figure 4d).

HEC adhesion on to PETP (series b). After $10 \mathrm{~min}$, some cell spreading on PETP was observed. After $30 \mathrm{~min}$, both the numbers of adhering HEC and the spreading area of individual cells had increased (Figure 5a). Smaller numbers of HEC in CMS adhered on to PETP than on to TCPETP (compare Figures 5a and 3b). However, after 1 and 2 h SEM (Figure $5 b$ ) showed many irregularly shaped HEC: many cells had elongated structures with detaching central parts (Figure $5 c$ ) and some cells had enveloped other cells (Figure 5d). When HEC had been seeded on to PETP in the presence of PBS and incubated for $30 \mathrm{~min}$, the morphology of the adhering and spread cells was similar to those described above for cells on TCPETP, i.e. a variety of cell forms was observed with SEM (compare Figures $6 a$ and $4 a$ ). 



Figure 3 HEC adhesion and spreading on to TCPETP. $4 \times 10^{4} \mathrm{cel} / \mathrm{s} / \mathrm{cm}^{2}$ were seeded from CMS. SEM micrographs (bar: 100 um) at 10 min (a) and at $30 \mathrm{~min}$ (b) show increase in both the number of adhering HEC and the degree of spreading. TEM micrographs (c, d) (bar: $1 \mu \mathrm{m}$ ) show cells with a circular morphology overlap of cell margins, cell-cell contacts, close contacts to the substrate, an adsorbed protein layer on the substrate and several vesic/es, both at the side of the substrate and at the luminal side.

The presence of 'footprints', remaining after detachment of cells, suggests cell death. An average distance of approximately $30 \mathrm{~nm}$ between the cell membrane and the substrate was measured. Further spreading was observed after the addition of CMS. The cells were able to keep the completely spread form, also after 1 and 2 h of incubation (Figure $6 b$ ).

HEC adhesion and proliferation on TCPETP and PETP in the presence of CMS and on protein-precoated surfaces (series c). No differences in cell adhesion and spreading on to TCPETP or PETP were observed when substrates had been pretreated with whole blood, plasma or $\mathrm{Fn}^{\mathrm{c}}$. Already after $30 \mathrm{~min}$, many HEC had adhered and spread. As an example, a photograph of a cell on PETP, which had been pretreated with whole blood, is shown in Figure 7a. The thickness of the preclot layer was found to be approximately $500 \mathrm{~nm}$. After $2 \mathrm{~h}$, the whole substrate area was occupied with spread and polygonal-shaped HEC (Figure $7 b$ ).

Initial proliferation experiments, in which $2 \times 10^{4}$ cells $/ \mathrm{cm}^{2}$ had been incubated with (protein-precoated)
PETP and TCPETP in CMS for $3 d$ showed HEC, which had formed confluent monolayers on untreated TCPETP and on whole blood- and $\mathrm{Fn}^{\mathrm{c}}$-pretreated substrates. Proliferating HEC, incubated with plasma-pretreated PETP and TCPETP, did not form a confluent monolayer (Figure 8a). In this case, cells entrapped within the fibrin network sometimes spread upside down' on the fibrin fibres (Figure $8 b$ ). No proliferation occurred on untreated PETP. HEC showed irregular morphologies on this substrate.

\section{DISCUSSION}

Several types of mammalian cells show an optimal adhesion on to moderately wettable substrates ${ }^{8-11}$. This observation was also confirmed by our studies using $\mathrm{HEC}^{4}$. After seeding of HEC either from PBS or CMS, numbers of adhering cells found on the moderately wettable TCPETP were always higher than those on the more hydrophobic PETP. Earlier results suggest that the ability of HEC to deposit cellular 

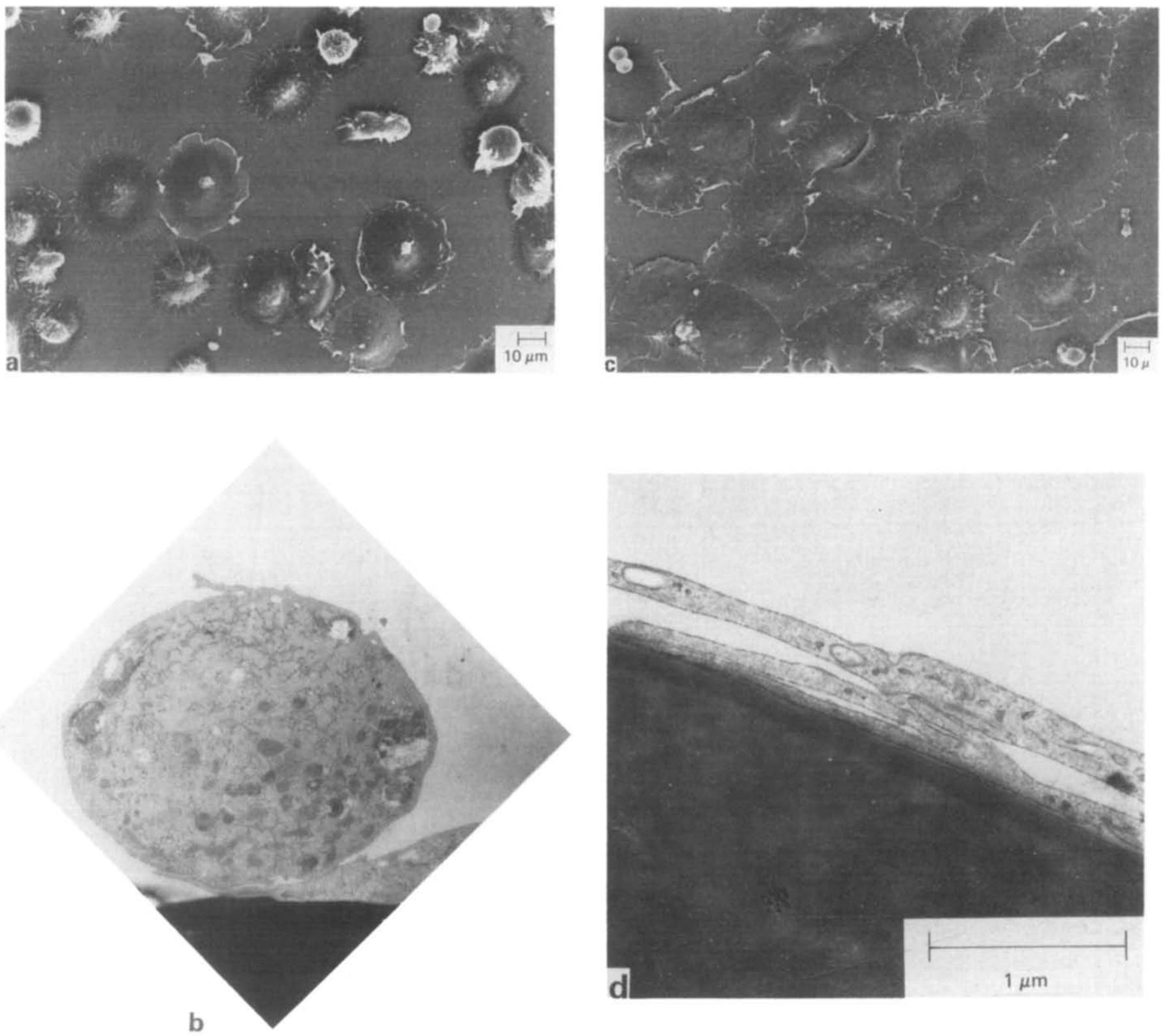

Figure 4 HEC adhesion and spreading on to TCPETP. $4 \times 10^{4} \mathrm{cells} / \mathrm{cm}^{2}$ were seeded from PBS. At 30 min, PBS was removed and replaced by CMS. (a) (SEM) shows a different cel/ morphology at 30 min in PBS; (b) (TEM) shows a spherical cell adhering to a cytoplasmic process of another (part/ly) spread cel/ 5 min after the addition of CMS; (C) (SEM) shows further cell spreading 20 min after the addition of CMS; and (d) (TEM) shows complex interdigitations of HEC 30 min after the addition of $C M S$.

fibronectin on a material surface is a condition for the spreading and proliferation ${ }^{12}$. It can be hypothesized that the deposition of cell adhesion-promoting protein(s), such as Fn, on TCPETP by HEC occurs to a larger extent as compared with PETP.

HEC spread completely on TCPETP and on both TCPETP and PETP, pretreated with whole blood, plasma or $\mathrm{Fn}^{\mathrm{C}}$ solution. The morphology of spread HEC corresponds with the structures observed by Haudenschild et al. ${ }^{13}$. When confluent, HEC show the typical 'cobblestone' monolayer pattern.

On PETP in the presence of CMS the spreading of HEC initially increases but decreases after 30 min (Figure 1). In this case, electron microscopy reveals the presence of non-spreading, partly spreading, overlapping cells, and cells which envelop each other (Figures $5 b, c, d$ ). Several factors may explain these observations. Possibly the secretion and deposition of adhesion-promoting protein(s) such as $\mathrm{Fn}^{14-16}$ by the cells is impaired. It is also possible that the conformation of $\mathrm{Fn}$ or another protein adsorbed on the hydrophobic surface may induce the irregular morphology. Grinnell ${ }^{17}$ suggests that $\mathrm{Fn}$ adsorbed on a hydrophilic substrate has a different orientation than Fn adsorbed on a more hydrophobic substrate. This author also indicates that Fn adsorbed on the hydrophilic substrate is biologically more active. Finally, it cannot be excluded that spreading of the cells may decrease due to an inability of recruiting cytoskeletal components and subsequent formation of the cytoskeleton $^{18}$.

The enveloping of one cell by another cell can be compared with the phagocytic behaviour of baby hamster kidney cells after exposure to small polymer particles as described by Grinnell ${ }^{19}$. HEC may also envelop other HEC because the adhesion receptors of the cells are no longer 

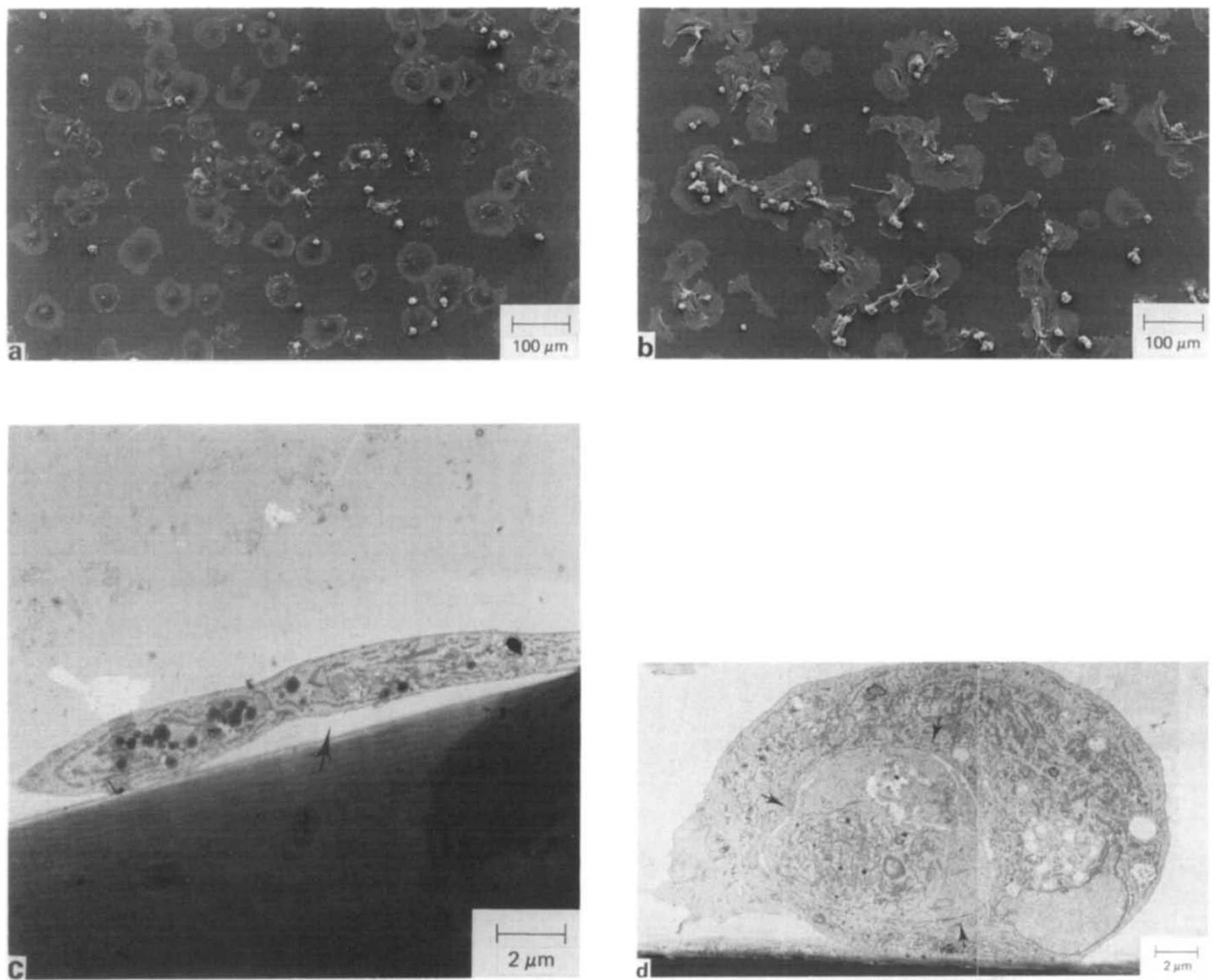

Figure 5 HEC adhesion and spreading on to PETP. $4 \times 10^{4}$ cells $/ \mathrm{cm}^{2}$ were seeded from CMS. SEM micrograph show cells with a circular morphology at $30 \mathrm{~min}$ (a) and irregularly shaped cells at $2 \mathrm{~h}$ (b). TEM micrographs show a cell with a detached central portion (c), and a cell which has enveloped another cell $(d)$.

able to interact with the substrate. In time, these incompletely spread cells will detach, since HEC need complete spreading for proliferation ${ }^{20}$.

A reduction in the number of adhering $\mathrm{HEC}$ occurred on both TCPETP and PETP, when HEC had been seeded from PBS instead of CMS. This is not surprising, since various cell

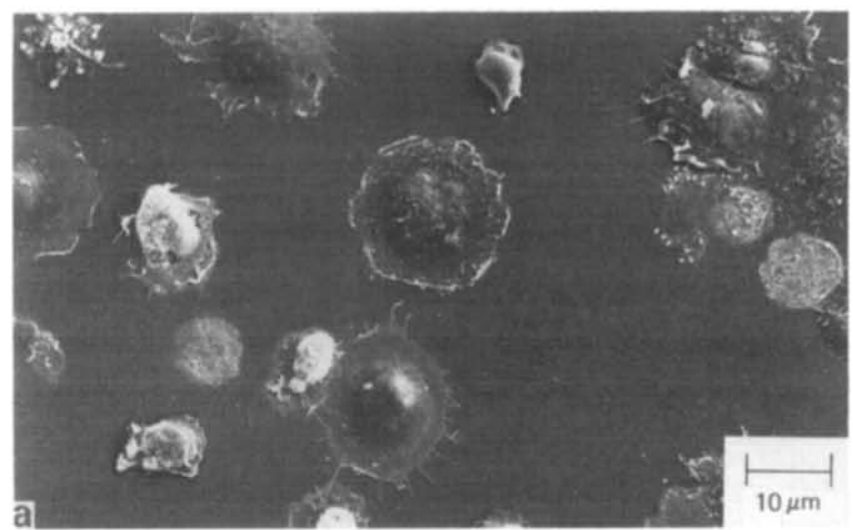

types are known to depend on $\mathrm{Ca}^{2+}$ in the culture medium for adhesion and spreading ${ }^{9}$. Cells on both substrates had different morphology compared with cells seeded from CMS (Figures 4a, 6a). Adhering HEC seeded from PBS are in closer contact $( \pm 30 \mathrm{~nm})$ with each of the two surfaces compared with adhering HEC seeded from CMS $( \pm 50 \mathrm{~nm})$.

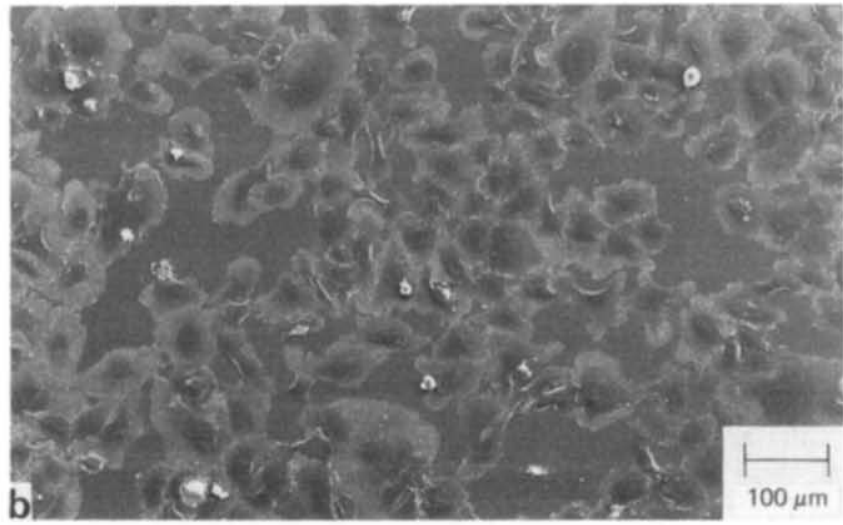

Figure 6 HEC adhesion and spreading on to PETP. $4 \times 10^{4} \mathrm{cells} / \mathrm{cm}^{2}$ were seeded from PBS. At 30 min, PBS was removed and replaced by CMS. SEM shows different cell morphologies and footprints from detached cells at $30 \mathrm{~min}$ in PBS (a), and a spread morphology $2 \mathrm{~h}$ after replacing PBS by CMS (b). 

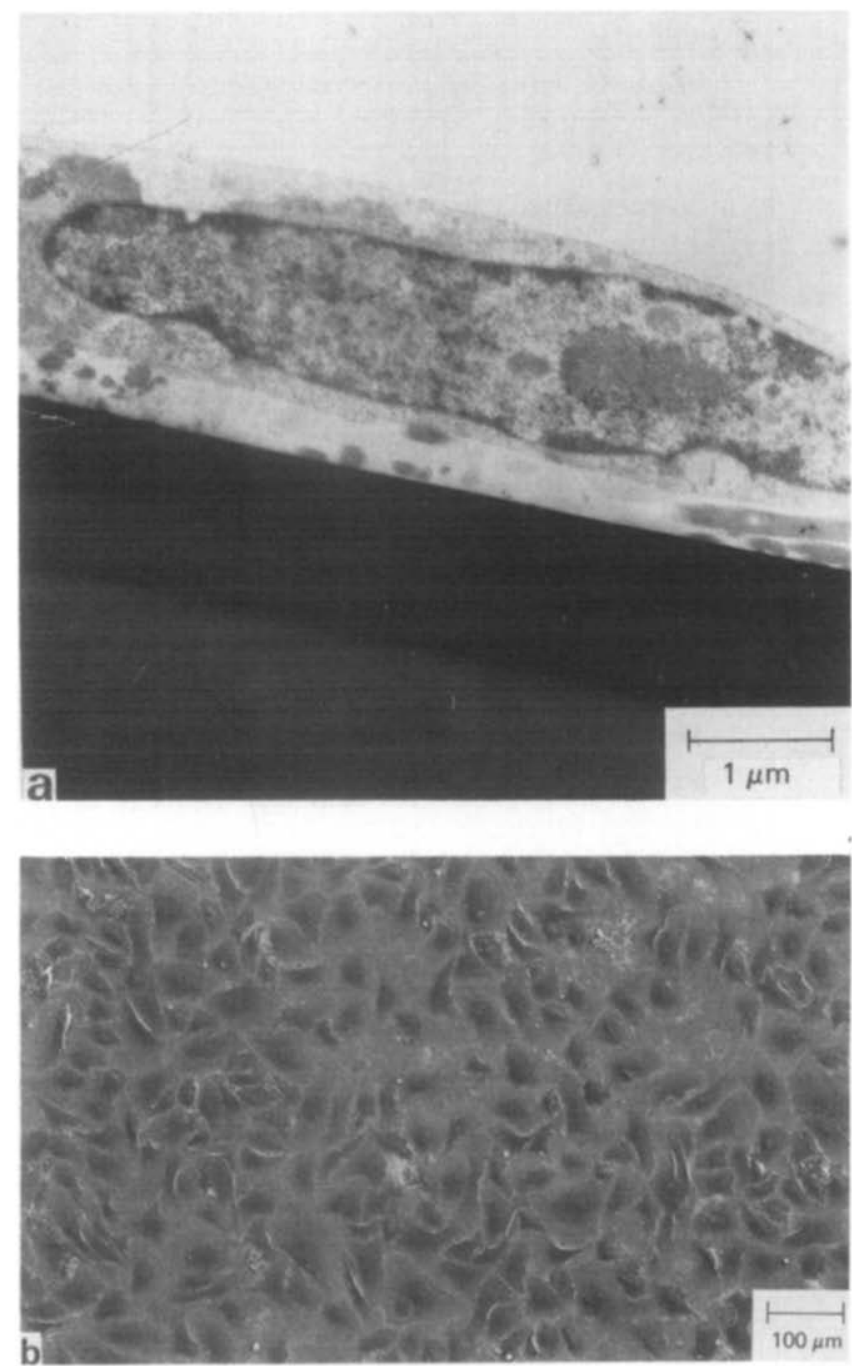

Figure 7 HEC adhesion and spreading in CMS on to protein precoated TC PETP. (a) (TEM) shows a spread cell on a thick proteinaceous adsorbed layer at 30 min on PETP, which had been pretreated with whole blood. (b) (SEM) shows the same surface covered with spread cells at $2 h$.

The absence of adsorbed serum proteins on the substrate must be the reason for this phenomenon.

The different cell morphologies, observed on TCPETP and PETP after HEC had been incubated for $30 \mathrm{~min}$ with PBS, possibly reflect variations in the phase of the cell cycle. Cells, which have recently divided, are known to detach from a surface more easily than cells in another phase of the cell cycle $^{21}$. Density and composition of certain cell surface receptors as well as the availability of cell adhesive proteins may vary within the cell cycle.

When PBS was replaced by CMS, the variations in morphology of HEC gradually disappear and 'normal' cell spreading occurs. Under these conditions, HEC not only spread on TCPETP, but also on PETP (Figures 2 and $6 d$ ). On PETP, spread cells are still observed $2 \mathrm{~h}$ after the addition of CMS. The initial close contact of HEC seeded on to PETP from PBS may be one of the reasons why the cells maintain the spread form after the addition of CMS. This was not observed when cells had been seeded directly from CMS. In the latter case, HEC probably form a cytoskeleton, due to the ability of the cells to produce and perhaps deposit proteins. Removal of these cells by trypsinization is more difficult, which indicates that a small amount of protein is present between the spread cells and the substrate.
During surgery, Dacron ${ }^{\circledast}$ (PETP) vascular grafts are preclotted with whole blood to prevent leakage after the blood flow has been restored. Dacron grafts, pretreated with plasma, which renders the preclot procedure superfluous, are also available. These pretreatment procedures result in the formation of a rather thick proteinaceous layer, and may therefore accelerate the process of 'pseudo-intima thickening'. This process is caused by smooth muscle cell- and fibroblastproliferation and is the major reason for late failure of grafts ${ }^{1}$. It has been demonstrated by Burkel et $a l^{3}$ that the thickness of this layer is significantly decreased after the seeding of autologous endothelial cells on the inner graft surface ${ }^{3}$.

Our results show that pretreatment of both substrates with whole blood, followed by extensive rinsing with PBS, results in a thick proteinaceous layer (Figure 7a). Furthermore, we demonstrated that proliferating HEC do not form a confluent monolayer when seeded on the plasma-pretreated substrates (Figures $8 a, b$ ). These results suggest that whole blood as well as plasma-precoating of Dacron (PETP), in combination with endothelial cell seeding, may not lead to an optimal endothelialization of grafts.
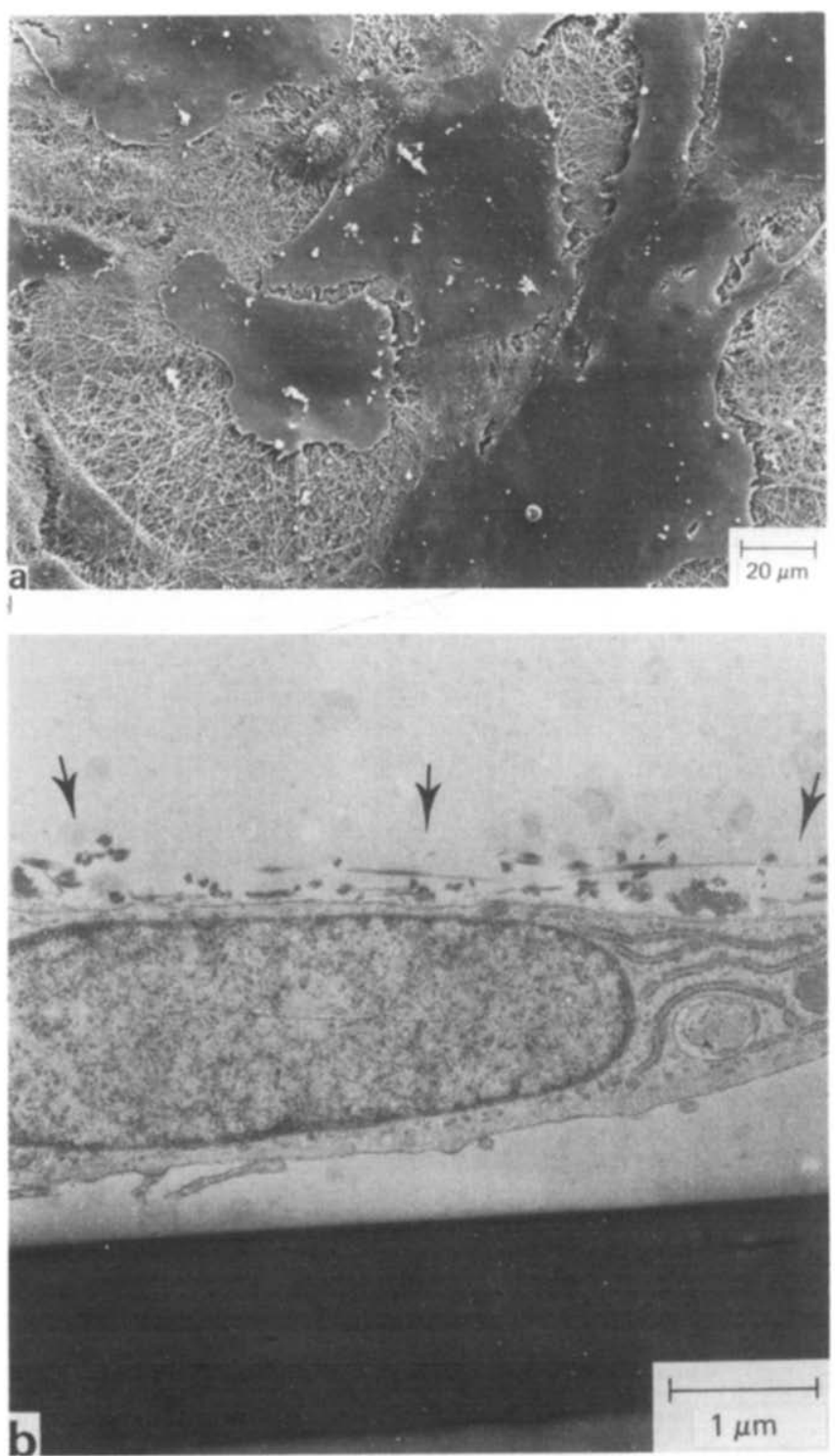

Figure 8 HEC proliferation at $3 d$ on PETP, pretreated with plasma. $2 \times 10^{4} \mathrm{cells} / \mathrm{cm}^{2}$ cells were seeded in CMS. SEM shows cells on top of a fibrin network and cells which have been (partly) entrapped within the network (a). TEM shows a cell, which has spread 'upside down' on fibrin fibres $(b)$ 
In conclusion, this in vitro study shows that TCPETP is, in general, a better substrate for cell spreading than is PETP, because adhering $\mathrm{HEC}$ are able to complete their spreading, whereas cells on PETP appear to withdraw from this substrate after some time. This suggests that vascular prostheses with a TCPETP-like surface will perform better in vivo than prostheses made of PETP.

\section{ACKNOWLEDGEMENTS}

We thank Mr F. Dijk from the Centre for Medical Electron Microscopy, University of Groningen for carrying out the scanning electron microscopic studies.

\section{REFERENCES}

1 Lindenauer, S.M., Experimental evaluation of Dacron knitted vascular grafts, in Biologic and Synthetic Vascular Prostheses (Ed. J.C. Stanley), Grune and Stratton, New York, 1982, p 523

2 Herring, M., Gardner, A. and Glover, J., A single-staged technique for seeding vascular grafts with autogenous endothelium, Surgery 1978 , 84

3 Burkel, W.E., Ford, J.W., Vinter, D.W., Kahn, R.H., Graham, L.M. and Stanley, J.C., Endothelial seeding of enzymatically derived and cultured cells on prosthetic grafts, in Biologic and Synthetic Vascular Prostheses (Ed. J.C. Stanley), Grune and Stratton, New York, 1982. p 631

4 Wachem, P.B. van, Beugeling, T., Feijen, J., Bantjes, A., Detmers, J.P and Aken, W.G. van, Interaction of cultured human endothelial cells with polymeric surfaces of different wettabilities, Biomaterials 1985 , 6. 403

5 Wachem, P.B. van, Vreriks, C.M., Beugeling, T., Feijen, J., Bantjes, A., Detmers, J.P. and Aken, W.G. van, The influence of protein adsorption on interactions of human cultured endothelial cells with polymers, J. Biomed. Mater. Res. 1987, 21, 701

6 Jaffe, E.A., Nachman, R.L., Becker, C.G. and Minick, C.R., Culture of human endothelial cells derived from umbilical veins. Identification by morphologic and immunologic criteria, $J$. Clin. Invest. 1973, 52 , 2745

7 Willems, Ch., Astaldi, G.C.B., de Groot Ph.G., Janssen, M.C., Gonsalves, M.D., Zeijlemaker, W.P., Mourik, J.A. van and Aken, W.G. van, Media conditioned by cultured vascular smooth muscle cells, Exp. Cell. Res. 1982, 139, 191

8 Schakenraad, J.M., Busscher, H.J., Wildevuur, Ch.R.H. and Arends, J. influence of substratum surface free energy on cell spreading of human skin fibroblasts in the presence and absence of serum proteins, J. Biomed. Mater. Res. 1986, 20, 773-784

9 Grinnell, F., Cellular adhesiveness and extracellular substrata, Int. Rev Cytnl. 1978, 53, 65-144

10 Schakenraad, J.M., Busscher, H.J., Wildevuur, Ch.R.H. and Arends, J The influence of substratum free energy on spreading of various cell-types on polymers, in Biological and Biomechanical Performance of Biomaterials (Eds P. Christel, A. Meunier and A.C. Lee), Elsevier Science Publishers bv, Amsterdam, The Netherlands, 1986 pp 263-268

11 Baier, R.E., Meyer, A.E., Natiella, R.R. and Carter, J.M., Surface properties determine bioadhesive outcomes: methods and results J. Biomed. Mater. Res, 1984, 18, 337-355

12 Wachem, P.B. van, Beugeling, T., Mallens, B.W.L., Dekker, A., Feijen, J., Bantjes, A. and Aken, W.G. van, Deposition of endothelia fibronectin on polymeric surfaces, Biomaterials 1988, 9, 121-123

13 Haudenschild, C.C., Morphology of vascular endothelial cells in culture, in Biology of Endothelial Cel/s (Ed. E.A. Jaffe), Martinus Nijhoff, 1984, pp 129-140

14 Jaffe, E.A. and Mosher, D.F., Synthesis of fibronectin by cultured human endotheliał cells, J. Exp. Med. 1978, 147, 1779-1791

15 Mackarak, E.J., Kirby, E., Kirk, T. and Kefalides, N.A., Proc. Natl Acad. Sci. US.A 1978, 75, 2621-2625

16 Reinders, J.H., de Groot, P.G., Dawes, J., Hunter, N.R., Heugten H.A.A. van, Zandbergen, J., Gonsalves, M.D. and Mourik, J.A van Comparison of secretion and subcellular localization of von Willebrand protein with that of thrombospondin and fibronectin in cultured human vascular endothetial cells, Thesis, Amsterdam, 1986 pp 55-62

17 Grinnell, F., The role of fibronectin in the bioreactivity of material surfaces, in Biocompatible Polymers, Metals and Composites (Ed. M. Szycher), Technomic, Lancaster, PA, USA, 1983, pp 673-699

18 Blose. S.H., The endothelial cytoskeleton, in Biology of Endothelia/ Cells (Ed. E.A. Jaffe), Martinus Nijhoff, 1984, pp 141-154

19 Grinnell, F., Fibroblast spreading and phagocytosis: similar cell responses to different-sized substrata, J. Cell. Phys. 1984, 119 58-64

20 Folkman, J. and Moscona, A., Role of cell shape in growth control Nature 1978, 273, 345

21 Folkman, J., Angiogenisis, in Biology of Endothelial Cells (Ed. E.A Jaffe), Martinus Nijhoff, 1984, pp 412-429 